\title{
Resenha
}

\section{O CORPO FALA}

(WEIL, Pierre; TOMPAKOW, Roland. O corpo fala. 51 ed. Petrópolis: Vozes, 2000)

Gislene Farias de Oliveira (1)

Este livro de Pierre Weil e Roland Tompakow, procura mostrar que existe uma linguagem manifestada pelo corpo a medida que entramos em contato com outras pessoas.

A temática da linguagem corporal já tem sido objeto de estudo de diversos especialistas e por isso já possuímos muitas informações interessantes sobre comunicações interpessoais.

A linguagem não-verbal é aquela em que interagimos por meios de gestos, expressões faciais e posturas corporais, e estas possuem vários significados dentro de um contexto. $\mathrm{O}$ reconhecimento destes sinais humanos podem ajudar numa comunicação mais eficaz, revelando estados de tensão, rejeição, aprovação, alegria e uma infinidade de outras mensagens. Podem também desmentir o que a pessoa fala, ou seja, discordar com aquilo que é expresso pelo verba. Neste caso, evidencia-se uma desarmonia que pode comprometer a comunicação.

Acontece em muitas ocasiões, quando nos expressamos de maneira contraditória entre a comunicação verbal e a comunicação não-verbal. Isso se dá porque, grande parte das nossas expressões não são controladas pelo nosso consciente. Assim, nem sempre temos o controle completo de nossas atitudes.

Algumas mensagens que têm significados diferentes dependendo da cultura e contexto da época. Isso porque a cultura influencia de maneira significativa alguns comportamentos humanos, de forma a tornar mais fáceis de serem reconhecidos.

Outras são mais truncadas e de difícil compreensão, uma vez que necessitam de uma maior habilidade de percepção. Quando não conseguimos tal habilidade, corremos o risco de gerar confusão nas nossas interpretações.

Segundo Weil e Tompakow, nas relações interpessoais, a comunicação não-verbal apresenta várias funções básicas como complementares à comunicação verbal. Por exemplo, um sorriso para concordar com algo, ou um manear de cabeça para os lados poderia substituir uma negativa.

Outra função da comunicação não-verbal é contradizer o verbal, uma discrepância entre os dois tipos de comunicação. Por exemplo, uma pessoa está demonstrando tristeza através da face e verbaliza estar muito bem à outra. 
Mais uma função da comunicação não-verbal é demonstrar nossos sentimentos e emoções como nervosismo, surpresa, alegria, dentre outras. Por exemplo: demonstrar surpresa ao levantar as sobrancelhas, ou ruborizar ao demonstrar timidez.

Os autores usam algumas imagens como referências para "traduzir" a linguagem corporal. Colocam as três partes da esfinge para mostrar como é dividido o homem: o boi, seria a referência aos instintos (ou desejos); o leão, aos sentimentos e, a águia estaria ligada aos pensamentos (ou consciência).

O homem somente conseguiria o equilíbrio, quando capaz de equilibrar ou, dominar os "três animais" dentro de si.

A mesma coisa aconteceria com os relacionamentos interpessoais. Não se existindo uma atração de águia para águia, de boi para boi ou de leão para leão, o relacionamento poderia tornar-se incompleto.

Um observador mais astuto poderá compreender os sinais com que as pessoas passam seus sentimentos. O corpo "fala" através de uma linguagem não verbal, complementando o que estamos querendo comunicar.

A forma como as pessoas se comportam, como colocam o seu corpo ou mesmo em que direção coloca os seus membros corporais, podem denotar um maior ou menor interesse, na nossa comunicação.

Para os educadores, essa linguagem pode ser muito importante. Afinal, são observadores diferenciados dos acontecimentos e das pessoas. Precisam estar sempre atentos aos seus interlocutores, sejam eles alunos, colegas de trabalho, pais. Ter pistas sobre se estes estão, mais ou menos atentos, se há a possibilidade de estarem mentindo, sendo sinceros ou nervosos. Enfim o corpo pode denunciar muitas situações que podem ser importantes, na hora de fazermos nossas inferências sobre nosso interlocutor.

O ponto negativo do livro está em sua linguagem um tanto repetitiva. Embora o ser humano seja muito menos observador do que realmente poderia ser, esse livro coloca situações muito obvias em termos de comportamento não-verbal. Durante nossa vida, aprendemos a compreender muitos dos códigos não verbais corporais. Assim, muita coisa que é discutida não se constitui numa novidade. Não há como se fazer um manual, como se não existissem pessoas capazes de comportamentos dissimulados, que escapam a nossa percepção intuitiva.

Um outro ponto a destacar neste livro é que a mulher aparece, na maioria dos desenhos, como inferior, subalterna, como "caça", até mesmo mostrada de uma forma pejorativa, como a sogra que tenta atrapalhar um relacionamento. Em contra-partida, o homem, sempre aparece como exemplo de altivez, numa posição bastante superior. Este tipo de imagem subjetiva pode intensificar um posicionamento machista, que em nada contribui com o que se pretende tratar com a temática enfocada. 
Por tratar-se de um livro com finalidades didáticas, essas observações são necessárias. Observe-se por exemplo: em nenhum dos desenhos aparece uma mulher, tentando seduzir um homem. Quando a relação é de trabalho, a mulher não aparece como chefe, conduzindo a ação.

A obra é muito interessante pois nos faz refletir e conscientizar de uma série de atitudes e mensagens que estamos emitindo e recebendo. Trás a tona muita coisa em relação a interação e a comunicação humana, mostrando o quanto a mesma transcende o verbal. Em contrapartida, talvez necessite ser repensada em alguns pontos, em caso de uma reedição.

\section{Sobre a autora:}

(1) Gislene Farias de Oliveira é Psicóloga e professora adjunta da Universidade Regional do Cariri URCA e Universidade Federal do Ceará - UFC.

E-mail: gislenefo@hotmail.com

\section{Como citar este artigo (Formato ISO):}

OLIVEIRA, G.F. Resenha. Id on Line Revista de Psicologia, Julho de 2010, vol.1, no.11, p.12-14. ISSN 1981-1189. 